\title{
DIVERSION FUNCTION OF WAQF LAND USE ON ISLAMIC LAW AND ACTS NO. 41 YEAR 2004 PERSFECTIVE
}

\section{ALIH FUNGSI HARTA WAKAF DALAM PERSFEKTIF HUKUM ISLAM DAN UNDANG-UNDANG NOMOR 41 TAHUN 2004}

\author{
Nilam Sari \\ State Islamic University of Ar-Raniry Banda Aceh \\ Jl. Ibnu Sina No. 2 Darussalam, Syiah Kuala, Banda Aceh \\ Email: habibiti1971@yahoo.com
}

Naskah diterima tanggal 28 Maret 2018. Naskah direvisi tanggal 17 April 2018. Naskah disetujui tanggal 18 Mei 2018

\begin{abstract}
This article discussed about stipulation of diversion of benefaction property function according to stipulation of Islamic law (fiqh) and laws No. 41 Year 2004 concerning to benefaction. Related to diversion of function of benefaction property use have happened some perspectives among of several theologians, there was part of theologian prohibited to change function and advantage of such benefaction of property, when such benefaction property in form of a building such as mosque, house and others. But in other hand, some theologians allowed change of function of waqf land during its original form do not changed and it not change to other name of such benefaction property. Such benefaction property which has diverse should be more strategic property, productive and empowered for religion and Islam community. Difference between Islamic law (figh) and positive law concerning to diversion of benefaction property function where in provision of fiqh jumhur of theologian was allowed the diversion of benefaction property function so long as do not change purpose of benefaction and do not change the object name which has donated. While the positive law was not regard such things, substantially it fulfilled economic value and productive and it not in opposition to law of sharia provision.
\end{abstract}

Keywords: Diversion of function, Waqf land, Islamic Law, Laws No. 412004.

\begin{abstract}
Abstrak
Artikel ini mendiskusikan serta membahas tentang ketentuan pengalihan fungsi harta wakaf menurut ketentuan hukum Islam (fiqh) dan Undang-Undang Nomor 41 Tahun 2004 tentang Wakaf. Terkait dengan pengalihan fungsi pemanfatan harta wakaf telah terjadi beberapa pandangan di kalangan para ulama, ada sebagian ulama melarang merubah fungsi dan manfaat dari harta wakaf tersebut, bilamana harta wakaf tersebut dalam bentuk bangunan seperti mesjid, rumah dan lainnya. Namun disisi lain, sebagaian ulama membolehkan perubahan fungsi tanah wakaf selama tidak berubah bentuk aslinya dan tidak berubah kenama lain dari harta wakaf tersebut. Harta wakaf yang telah dialihkan itu harus menjadi harta yang lebih strategis, produktif dan terbedayakan untuk kepentingan Agama dan umat Islam. Perbedaan antara hukum Islam (figh) dan hukum positif tentang pengalihan fungsi harta wakaf dimana dalam ketentuan figh jumhur ulama membolehkan pengalihan fungsi harta wakaf asalkan tidak berubah maksud wakif dan tidak berubah nama benda yang diwakafkan. Sementara hukum positif tidak memandang hal yang demikian, yang penting memenuhi nilai ekonomi dan produktifserta tidak bertentangan dengan ketentuan hukum syariah.
\end{abstract}

Kata kunci: alih fungsi, harta wakaf, hukum Islam, UU No 41 tahun 2004

\section{INTRODUCTION}

$\mathrm{I}$ $\mathrm{n}$ development of Islamic history, waqf already performed by Muslims from early period in time of the messenger of God Saw. As for waqf implementation which first time implemented in Islam was waqf carried out by disciple that was Umar
Ibn Khattab to his land in Khaibar (Sabiq, 2004: 426). Some of the closest disciples of messenger of God even intend to donate his whole plantation land and properties. Waqf is one of a pure muamalah activity form of teachings of Islam. Thought of waqf in Islam is a discovery there is no comparison in history. The thought of waqf be completed in time of disciples 
and next Islamic generation. According to Jabir bin Abdullah, there was no one among of disciples who have land and building except there were donated it (Qahaf, 2005: 15-16)

Basically, waqf is one of worship activity that most recommended to conducted by Muslims, because it will always aim the reward to waqif (person who donated) although person involved has passed away. Since and after coming of Islam, mainly of Muslims in Indonesia performed waqf based on religious opinion followed, that was Syafi'iyah and local tradition and custom.

Fiqh Ulama (Muslim Scholars) give an opinion that use of property for benefaction was also covering benefaction by waqf. They assess that it was include category of alms which its reward value always aim as the profit can be picked. This is the cause waqf in Indonesia more emphasized in case of donation of land. This is not mean that waqf except of land is not be accredited, but this regulation was considering the land as valued object which many make problems in society. Moreover, land as moving objects and durables and has a high economic value. The lands a place constructed of mosque of Muslims since in the past commonly constitute of waqf at that time, although in implementation was not have yet administrative regulation as now (Karim, 1993: 116).

In fiqh review deal with transfer of waqf land function in Islamic law there was different of opinion in among of Ulama. Some are allowed and others prohibited. Some of Ulama of Syafi'iyah (Muslim scholar of mazhab Syafi'i) and Malikiyah Muslim scholar of mazhab Maliki) argued, that waqf objects which have not functions, persisted may not for sale, exchanged or substituted and dislocated. Because base of waqf is eternal, so that any condition the waqf object must be allowed in such manner. Basic of they used was hadist of prophet Saw which narrated by Ibnu Umar, where said that waqf objects may not for sale, donated and may not inherited. While according to other Ulama such as Imam Ahmadi Ibnu Hanbal, Abu Tsaur and Ibnu Taimiyah the law is may to sale, change and substitute or dislocate such waqf object. Such permit, both by the reason in order to waqf object can functions or making benefit correspond to waqf purpose or to get bigger benefit for public interest, especially for Muslims (Al-Munawwar, 2005: 127).

In stipulation of Act No. 41 Year 2004 Concerning Waqf, in Article 40 was also regulate on change waqf land which have regarded not or not quite function as aim the waqf itself. In principle, waqf properties which have donated are forbidden to: (1) Made as assurance; Confiscated; (3) Granted; (4) Sale; (5) exchanged, or; (6) Diverted in form of redirect other right. Regard to phenomena and problematic of donation, need presence specific study related to use and redirect function and utilization of waqf property become more systematic and good, so that essence of waqf activity can be running well, so that functions and benefit and objective were declared waqf perceived benefit.

To create essence and objective of waqf can be achieved well, so need presence clear legal stipulation related to use, redirect of function from land status of waqf that should be protected for public prosperity accord with objectives, function, and waqf allocation and correspond to Islamic Law and of Acts No. 41 Year 2004 concerning to Waqf. In Stipulation of Acts No. 41 Year 2004 Chapter 40, Article 41 and Chapter X Article 69. As known, the Islamic Law was a manual for whole Muslims to implement all things to be not swerve from rules which have regulated by Allah SWT. Likewise Acts are rules which have regulated by government in such a manner for the purpose to perform all activities in people life. In this case, Acts No. 41 Year 2004 concerning to Waqf aims to advance public prosperity. One of strategic step to increase the public prosperity is need improved of waqf role as institution of religiousness which not only aims to prepare various worship and social facilities. But also have potentially economic power, among others to advance public prosperity, so that need developed its utilization correspond to principle of syari'ah. This article is aims to discuss of stipulation of change of waqf land regarded from Islamic Law.

\section{Understanding of Waqf Legal Basis}

Basically, word of waqf was originated from Arabic al-waaf (الوقف) its mean al-habs الحبس ) Word of waqafa - yaqifu - waafan.وقفيقفوقيا:), its means habasa-yahbisu-habsan (حبسيحبس (Sa) (Sabiq, 2006: 432) Al-waaf (الوقف) means is stop, stopping or stand, and al-habs (الحبس) means imprison, prevent or hold up.(Nuh, et.al, 2001: 75) Word of al-waaf in Arabic containing mean is "hold up" hold up property to donated, not transferred.(2007: 1). In a lot of definition mentioned that waqf in language is same with word of al-habs (الحبس) that is hold on deeper means keep someone from something or imprison and then develop into habbasa that means donated the property because of Allah (Kartika, 
2006: 54). According to Sayyid Sabiq, waqf means hold the property and give the benefit in the way of Allah (Sabiq, 2006: 423).

In view of ushul fiqh, waqf means standing, stop and can given meaning eternal, the plural is auqaf which contains the meaning sense giving the property by sincere or appropriate with giving which prevail eternal to interest Islamic government, religious interest, and or public interest. Such fund is used for care and interest of mosque. Usually, this giving can be withdrawn back by benefactor party. Characteristic of waqf giving is that the giving to forever (2005: 358).

In terminology of syara' waqf is a kind of giving which implementation by hold beginning (ownership) (تحبيس الأصل) then make the benefit generally accepted. The meaning of (تحبيس الأصيل) "hold something is hold the object donated or in order to be granted, used in form of on sale, bequeathed, pawned, rented, borrowed and its kind. Whereas way to use it is using by appropriate to benefactor's wish without rewards (Mughniyah, 1995: 635). Waqf is prevailing forever and continue. Ulama of mazhab except Maliki argued that waqf is intangible unless the benefactor would like to donated the objects for forever and continue. That is the cause so it called as shadaqah jariyah (1995: 635).

In Al-Qur'an, waqf was not mentioned clearly and explicit, but the existence is inspired by verses of Al-Qur'an and example from Allah apostle Saw and tradition of disciples (Al-Munawwar, 2005: 124). One of verse used by fiqh experts as basis of waqf law, that is word of Allah in Al-Qur'an Sura Al-baqarah verse 267.

\section{Basis Legal of Making Shari'a of Waqf}

Basically, waqf is one of means to increase quality and quantity of worship to Allah has main foundation was Al-Qur'an and Hadits, because as a worship, the waqf has been adjusted its legal stipulation by Allah SWT. The stipulation of waqf, although and other worships which will do by human as means to get closer to Allah.

In Al-Qur'an was very much presence verses as basis be made argumentation to do the waqf, although the verses in Al-Qur'an were not told special on waqf, just because the waqf was one of benefaction and deed forms by means property so Ulama also understand that the verses of Al-Qur'an which command the Muslims to maximize use of the property for benefaction were also covered benefaction by waqf.
Related to problems of basis of Waqf legal, there was several verses of Al-Qur'an explains on donation in general, among others as follow:

Words of Allah SWT in Al-Qur'an sura AlHajj verse 77:

$$
\text { و افعلو ا الخيرلعلكمتفلحون }
$$

Its means: ....and do good that you may succeed. (Q.S. Al-Hajj: 77)

Afterward word of Allah in sura Ali Imran verse 92:

$$
\begin{aligned}
& \text { لنتنالو ا البرحتىتنفقو امماتحببون } \\
& \text { \% }
\end{aligned}
$$

Its means: Never will you attain the good (reward) until you spend (in the way of Allah) from that which you love...(Q.S. Ali Imran: 92)

From several mentioned verses can be understood that explanation on waqf is indeed explained generally. However, in outline through the verses, Allah SWT commands the use of property for benefaction to get the glory and perfect degree. One of way to reach the glory was by spend some the best property possessed in way of Allah such as waqf to get ridha of Allah (al-Maraghi, 1993: 21). Afterwards, to specialize such verse will be specified the legal stipulation with hadits that explains specially about waqf.

In addition, messenger of God in hadits narrated by Abi Hurairah said:

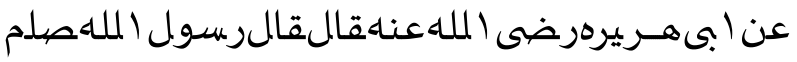

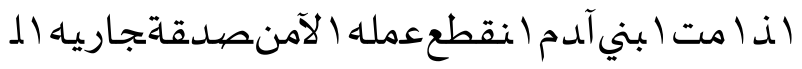

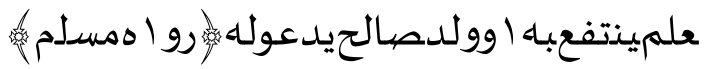

Its means: From Abi Hurairah ra., in truth Apostle Saw said: If Adam's child was passed away, so broke his deed, except three matters, that was: shadaqah jariyah, useful knowledge or godly child who prayed for her/his parents. (HR. Muslim).

From such hadits can be understood that, aim and the use of waqf property was very useful and help if a human is passed away later was shadaqah jariyah. If during the time his life in the world someone was often do benefaction to other such as waqf, so the reward of the waqf will not broken and will keep flow to that person though he/she is gone. Because by donated, it helps greatly for many people. Thereby, Allah SWT very recommends for His servants for much to do good deed. 
Based on word of Allah and such hadits of Apostle Saw, so can be concluded that waqf is a very useful deeds for human because the reward continue which not quite to flow back to the wakif (who give waqf), which was immeasurable gift, moreover when passed away, where the deeds could be done more, but with presence the reward from waqf, so it will very help existence of wakif.

\section{Purpose of making syaria and using of Waqf Property}

Basically, the purpose implementation of waqf is to find out the willing of Allah for the property were possessed by a Muslim because a property that possessed is meaningless without have the willing of Allah both in possession and when he/she has die because life of this world is aim to other life phase that was barzakh world and judgment day. This is corresponding to Commandment of Allah and Hadits Allah's apostle Saw.

As for the purpose of waqf property can be classified as follows:

1. Waqf fo public benefit

Waqf to create public benefit is aim to help tool and infrastructure which can be used by whole Muslims. Many tools and infrastructures were built by using waqf property that classified from category of waqf khairy. The waqf land addressed by wakif for public interest usually used agree with promise of waqf that be done by the wakif, either to construct education building, mosque, mushalla or the others. Thereby, the waqf property can give very wide benefit for the Muslims.

Basically, waqf which addressed for public benefit have role that can be ignored to advance and keep syi'ar Islam (Khallaf, 1963: 6). In Islamic history, this case has been done by disciples, where in the past they have donated their property for interest syi'ar of religion beginning from donation of small objects such as donation of arrow that be done by Umar bin Khatab in Khaibar War as narrated by Syafi'i until donation of land include a well that be done by Abu Thalhah in Madinah (Sabiq, 2006: 132).

\section{Waqf for family}

Purpose of waqf is to help life needs of members of family from wakif, because his life needs was not fulfilled. By presence the waqf of member so needs of family members can be fulfilled by utilize the waqf property which given by the waqf maximally. Waqf addressed to family by the purpose to help his family's needs, has performed in time of Allah's apostle that was where Abu Thalhah was donated Baihara for relatives and his uncle children (Sabiq, 2006: 132)

From explanation above can be understood that purpose of waqf in Islamic shari'a basically is to find out and reach of ridha Allah for property were possessed by someone was not just benefited by the owner, but also given to public interest. While in particular purpose was to aid needs that lived by Muslims and family clan of wakif.

\section{The use of Waqf Property}

Basically, the use and utilize of waqf property is adjusted to the purpose declared by wakif that has determined when donation was implemented. Suppose the waqf was addressed to his family and intended by the wakif in order the beneficiary use it to life beneficence of them.

Concerned with use of waqf property, in this case Ulama were having different arguments. of course it was caused by the different visions on possession of property and waqf land. According to jumhur of Ulama, property is moved from wakif to mauquf 'alaih. Its means was, after giver of waqf (wakif) gives his property to be donated, so directly right of the ownership is moved from wakif to beneficiary who entrusted to manage or using the property donated. Therefore, mauquf 'alaih can manage maximally to his life's interest. If kind of waqf was zhurry, so family clan of wakif may use the waqf property were received for his interest of life. If the waqf was khairy so it can be used to people and religion interests appropriate with defined purpose by wakif in the pledge of waqf. (Zahrah, 1971: 30)

In view of Imam Abu Hanifah, the waqf property may be possessed by wakif while which given to mauquf' alaih was only benefit of such waqf property. So making efficiency use of the waqf must in this context was very limited and just bound to benefit (Khallaf, 1963: 60)

Making efficiency use of the waqf property should be done in things permitted by shara' (canon lawa) and benefitted to interest of mauquf 'alaih. Such benefit should be done maximally in order the waqf property were not left, so that wakif and the mauquf 'alaih can get the benefit from such waqf property. Wakif can acquire reward and the mauquf 'alaih can use the waqf property.

In view of Al-Qurthuby, has familiar for board benefit of the waqf property. To nazhir who manage waqf property should be given some from 
results of waqf property for interest and his needs of life (Sabiq, 2006: 150).

Allah's apostle Saw and disciples have applied this waqf worship and used waqf property appropriate to the purpose of waqf which defined by wakif, by benefited the waqf property much life problems were helped both for religious needs and for life's needs of Muslims, depend on kind waqf property given by wakif. Thereby, for current, it's the time the Muslims making efficiency use of waqf property professionally by using a good managerial (management or regulation) in order waqf property were have high economic value.

\section{Opinion of Ulama about Waqf Property Status}

Basically, all waqf properties must be benefited and utilized correspond to pledge of settlement which has been pronounced by the wakif when he/she donated the property. The waqf property should be utilized to place intended by the wakif. Waqf property must be used in place expected by the wakif. Wakif who have give his/her property for donation, both khairi waqf and zhurry waqf, should shows benefit of the waqf property for things or in mubah (neutral) place according to Islam Shari'a conception. Therefore, the use of waqf property should be functions as maximal as possible by using well management methods.(Al-Siba'i, 1964: 150).

By existing of well waqf property management, so purpose of waqf from wakif will be fulfilled and value and form of such waqf property will be achieved or appropriate to objective and purpose of implementation the waqf itself. So that achieved benefit and purpose of the waqf property itself.

In views of mazhab Syafi'i argued, if waqf land is used for street, so it be changed of functions, from the beginning the street become to a lot for building of mosque or for extend the mosque if any it have narrowed location. Because the mosque be built and extended for Muslims interest too. However, in case of transfer of street become to lot of mosque, be conditioned was not disadvantages for street user, both Muslims and infidel (Zahrah, 1971: 164).

Basically, management of waqf property itself to achieve the purpose of waqf carried out by nazhir. The nazhir who managed some of them was collective and also individual. In their application, not all means of donation can achieved well, because a lot of things that become obstacles to release the aims of donation. For instance, wakif has defined that land to be donated is used to build mosque in that place. However, because of the location was not strategic, so that the mosque was built at other place. By not built the mosque at that donated land, so the land is neglected and not utilized. Like this condition lead to the waqf land tend to abandoned not any benefit and therefore need to find out the solution. The solution among others was by change function of waqf property into other form.

\section{Analysis of Waqf Property Functions According to Islamic Law and Legislation in Indonesia.}

Related to alteration of function of waqf property, there was the difference of opinion in circle of ulama. There were some permitted it with particular conditions and there were also that not limited alteration of waqf property function. In detail there are three categories of waqf property namely:

\section{Mosque}

In the views of Imam Malik, the mosque is may not to be changed for its functions and shape to be other shape. The mosque was also may not to commercializing and be valued by money, because the mosque should be kept and maintained in its intact form as its form of origin and may not be converted become other place.

\section{Immovable Object}

As for form of immovable object such as land and house were may not be changed or on sale with a kind object. Although the house has collapsed, moreover if alteration of form was be done with exchange of a kind object, this measure according to Imam Malik was strictly prohibited. However, sales of waqf objects that include in this category can be performed if used to extend the mosque or be affected street broadening.

\section{Moving Object and Cattle.}

In context of moving object and cattle, when such object condition cannot be used more, so may be sold and substituted with the new one and a kind. As property donated in form of cattle, form of buffalo for used for plow up, if the buffalo is old so it can be sold for the selling price is sold to other buffalo, which more can be utilized in maximal. The donation in form of cattle the benefit that can be obtained can be utilized repeatedly, such as milk, hair and others (Jauzy, ttp: 371).

Make reference to other opinion, which allowed sold the waqf property if it cannot be utilized or damaged so that can be substituted with a kind property which more effective and has a potential economic value. This is as in view of 
Syeikh Kharsy, he given an opinion that if waqf land is left empty no utilized for economic valued, so it better functions for other thing of mubah according to views of syara', and such property in form of a building both mosque and house, and has damaged so repaired or be sold and its selling price is to buy another buildings which have same quality or better(al-Syirazy, tth: 445).

According to opinion of Syafi'iyah group, the waqf property has to be defended for the a'in although have broken some, while other parts were still can be utilized. This is means that waqf property is can be converted or sold and substituted with another property. However, most of ulama of Syafi'iyah have argument that land and immovable object were may not substituted. While some others ulama of Syafi'ah argued that, land and others moving objects such as mosque building, can be substituted or shifted of the functions due to give priority to other interest which more important to the goodness of people, for instance redirects of waqf land functions from mosque garden into street, because the streets was more needed for Muslims (Zahrah, 1971: 162).

From such explanations can be understood that some of ulama syafiiah give opinions that change of the waqf property function can be done because regarded from the benefit that more needed by people. In reference to cattle, in particular riding animal can be substituted or sold and repurchased of other animal which is similar and can be used in Allah's way. If the riding animal is already weak and can be used more for importance in way of Allah, so the law was may to be sold and the price is used to buy other animal which is similar even finer (Abidin, 428).

Related to change of function of mosque or modify of mosque form, according to opinion of most ulama mazhab Syafi'iyah should not be done. As well as if the waqf property in form of land, so remain should not be changed the function. The waqf land should be function correspond to giver desires. Mazhab Syafi'i was prohibit to sell waqf land sublimely, although it already cannot used or function anymore. This prohibition is extremely firm, even if the property which donated in form of the tree and it has productive anymore, so remain prohibited sold it, because the mauquf 'alaih was can use it in another form.

According to views of Ibnu Qudamah alHanbali argued that property which has donated by the waqf giver, when the property has been broken or cannot used anymore so it may changed for the form and functions by condition that fulfilled stipulation of syara'. For example, mauquf in form of land, but such land was cannot be used or utilized anymore, so it maybe changed of form and functions. Although, initially, waqf giver was donated the land for used as a farm. In such condition, the mauquf 'alaih can change land status by selling it to other or to change the land functions from a farm and then into other functions, such as to build the building that has economical value or for mauquf'alaihi (alHambali, 575)

Basically, benefit and the goodness of waqf land are most important thing to created in waqf. Thereby, a factious thing if keep defends the mauquf in original form, whereas its benefit was cannot obtained by the mauquf 'alaih so that the mauquf is unfinished and useless. Mauquf'alaih can endeavor according to its ability to realize the goodness and benefit for live and the life. Of course this matter is aim to create the increasing of benefit of such waqf property.

From various explanations and discussion above can be understood that, in particular context the waqf property was may not function, but most of ulama were permitted the change of waqf property functions, but the exchange was should similar to formerly object, both kind and the functions. That thing may be done if be based to public interest, because the public goodness was more priority if compared with defending original form of waqf property.

Likewise about change of waqf land function, permitted to change its function, especially if conducted to avoid the occurring of disadvantage in society, and has purpose to create people benefit. For instance the waqf land for mosque can be shifted the function to build the street, cemetery, and others and people facilities which got much benefit, due to such function change is important to benefit of Muslims. Moreover, if there was no other land to build the street or make the cemeteries or others people benefit place. If other land is any, so change of the function may not be done.

In stipulation of Islamic Law Compilation (ILC) as application law for Muslims in Indonesia given a view associated with likely of converted or change of waqf property status that apparently its use was not felt anymore by people. The stipulation was explained in Article 225 Islamic Law Compilation, said that clause (1) explained that basically toward donated properties cannot do the change or other 
use from intended in waqf promise. Whereas in clause (2) declared, variance of the stipulation in clause (1) only can be done to particular things after former got the writing approval from Sub District Head Office of Religious Affair based on recommendation from Sub District Majelis Ulama and local Sub District Head by reasons: 1) Due to inappropriate anymore to the purpose of waqf like declared by wakif, b) Due to public interest.

According to Acts Number 41 year 2004, Article 40 and Regulation of Government Number 42 year 2006 that the waqf properties were be made as assurance, confiscated, granted, sold, inherited, and substituted. However, change of status or exchange of waqf property can be done if the waqf property which has used for public interest corresponds with general spatial plan based on stipulation of valid law and regulations and not be in contradiction to syariah. And for religious needs.

Further, in article 41 Acts No. 41 year 2004 mentioned that: 1) Stipulation as intended in article 40 excepted if waqf properties that have donated used to public interest appropriate to general spatial plan based on stipulation of valid law and regulation and not be in contradiction to syari'ah. (2) Implementation of stipulation as mentioned in clause (1) only can be done after get the writing permit from Minister upon approval of Indonesia Waqf Institution.

Furthermore, in article 44 Acts No. 41 year 2004 mentioned that: (1). To managing and developing of waqf property, nadzir be forbidden do the change of allocation waqf properties except on a basic of writing permit from Indonesia Waqf Institution. (2) Permission as mentioned in clause (1) only can given if the waqf properties apparently cannot to be used in accordance with the allocation which declared in waqf promise.

As is the case happened in time of comrade Umar ibn al-Khattab, when he donated his land, he himself acts as nadzir during his lifetime. After his passed, waqf management was given to his daughter Hafsah. Afterwards, handled by Abdullah ibnu Umar, then other Umar family, and then based on testament of Umar. This is proven that the nadzir is very needed for success of waqf purpose.

Thereby, so apparatus of executor and waqf manager (nadzir) should has a good education and morality and has adequate skill, so that the waqf object can be managed optimally. Furthermore, it is deemed necessary presence of improvement of work ethos that more effective and efficient. On that basis, needed to be held cooperation from all parties, both from KUA party and socialization to people that waqf properties is collective responsibility whole of Muslims, so that people comprehension about management of waqf property can run according to purpose.

\section{CONCLUSIONS}

Waqf is one of worship activity form which very recommended to do by Muslims, because the waqf will always aim the reward to waqif (person who donated) although person involved has passed away. Since coming of Islam to archipelago, most of Muslims in Indonesia performed the waqf based on religious concepts were professed, that was Syafi'iyah concept and local custom. Related to transferring of function of waqf property use has happened some opinions in the circle of ulama, there are some forbidden to change function and use of such waqf property, when such waqf property in form of building such as mosque, house and others.

However, on the other hand, some of them were allowed change of waqf land function during not change its original form and also to the other name from the waqf property. The waqf property that has transferred should be more strategic property, productive and useful for religion and Muslims interests. Difference between Islamic law (fiqh) and positive law concerning to transfer of function waqf property where in stipulation of fiqh jumhur of ulama was allowed for that so long as do not change intent of waqf and do not change the name of objects were donated. While positive law was not regards such matter, an important is economic value is exists and more productive.

\section{ACKNOWLEDGEMENT}

The article which is the result of librarybased research that seeks to examine the transfer of wakaf's properties involves the assistance of several parties who actually get appreciation in the form of acknowledgments, especially on al-Qalam journal managers who have facilitated the editing process until the publication.

\section{REFERENCES}

Abdullah Bin Nuh and Oemar Bakry, Kamus ArabIndonesia-Inggris Indonesia-Arab-Inggris, Ed. 13, (Jakarta: PT. Mutiara Sumber Widjaya, 2001.

Ahmad Mustafa al-Maraghi, Tafsir al-Maraghi, (Trans. Bahrun Abu Bakar and Hery Noer Aly), Semarang: Toha Putra, 1993. 
An-Nawawi, Syarh Shahih Muslim, Juz XI, Egypt: Marthba'ah a-Mishriyah, 1924.

Abdul Wahab Khallaf, Ahkamul Waqfi, Cairo: Mathba'ah, 1963.

Abu Ishaq asy-Syirazy, Al-Muhazzab, Vol. I, Egypt: Mathba'ah al-Baby al-Halaby, t.t.

Direktorat Pemberdayaan Wakaf dan Bimbingan Masyarakat Islam, Fikih Wakaf, (Jakarta:2007).

Elsi Kartika, Hukum Zakat dan Wakaf, Jakarta: Grasindo, 2006.

Helmi Karim, Figh Muamalah, Jakarta: Raja Grafindo Persada, 1993.

Ibnu Abidin, Hasyiah Raddul Mukhtar, Vol. III, Cairo: Mathba'ah al-Baby al-Halaby, t.t.

Ibnu Qudamah al-Hanbali, Al-Mughniy, Vol. V, Ed. III, Cairo: Dar al-Manar, t.t

Imam Muslim, Shahih Muslim, Juz II, Bandung: Mathba’ah Dahlan, t.t.
Mundzir Qahaf, Manajemen Wakaf Produktif, Jakarta: Khalifa, 2005.

M. Jawad Mughniyah, Fiqih Lima Mazhab, (Trans. Masykur, A. B, et all), Ed. 1, Jakarta: Lentera, 1995.

Muhammad Abu Zahrah, Muhadharat fi al-Waafi, Ed. II, Dar al-Fikr Al-Araby, Bairut, 1971.

Musthafa as-Siba'ly, Sistem Masyarakat Islam, (Trans. A.H. Malik Ahmad), Jakarta: Mulia, 1964.

Totok Jumantoro, Samsul Munir Amin, Kamus Ilmu Ushul Fikih, Ed. 1, Jakarta: Amzah, 2005.

Acts No. 41 Year 2004 Concerning to Wakf

Sayyid Sabiq, Fiqh Sunnah, Vol. 4, Ed. 1, (Tran. Nor Hasanuddin, et al), Jakarta: Pena, 2006)

Sayyid Sabiq, Fiqh Sunnah, vol. 14, (Trans. Muzakkir AS.) Bandung: Al-Maarif, 1988.

Said Agil Husin Al-Munawar, Hukum Islam \& Pluralitas Sosial, Jakarta: Penamadani, 2005. 